\title{
フィルターユニットで被覆した 緩傾斜護岸の耐波安定性 THE STABILITY OF THE MILD SLOPE REVETMENT ARMORED BY FILTER-UNITS AGAINST WAVE ATACK
}

\author{
秋山真吾 $1 \cdot$ 池谷毅 $2 \cdot$ 今藤久夫 $3 \cdot$ 高橋忍 $4 \cdot$ 石川芳一 5 \\ Shingo AKIYAMA, Tsuyoshi IKEYA, Hisao KONDO, Shinobu TAKAHASHI \\ and Yoshikazu ISHIKAWA

\begin{abstract}
1正会員 工修 鹿島建設株式会社 技術研究所（广182-0036 東京都調布市飛田給二丁目19-1）
2正会員 工博 鹿島建設株式会社 技術研究所（T182-0036 東京都調布市飛田給二丁目19-1）

3正会員 鹿島建設株式会社 土木技術本部（广107-8388 東京都港区元赤坂1-2-7）

4非会員 鹿島建設株式会社＼cjkstart関西支店（T550-0011 大阪府大阪市西区阿波座1-3-15）

5非会員 キョーワ株式会社（广542-0081 大阪府大阪市中央区南船場1-13-20）
\end{abstract}

The conventional method used for covering shore protection by armor stones needs not only much time for processing stones but also many divers for averaging the rubble mound, setting up and leveling stones for armoring, thereby postponing work period and leading to rise of cost.

So we have designed a new method called filter-units in place of armor stones and performed hydraulic model tests to make clear those characteristics. The filter-units consisted of small stones and wrapping nets, have abilities of reducing work period. In this paper, we firstly explain the characteristics and the construction methods of filter-units. Secondly, we detail the result of the hydraulic model test. It was found out that filter units have excellent flexibility and suitability for waves equal to that armor stones have.

Key Words : filter-unit, mild slope revetment, armor stone, rubble, reduction in work period, hydraulic model test, suitability for waves

\section{1.はじめに}

護岸などの築造に用いられてきた従来の被覆石工 法は，使用する被覆石の加工に手間がかかるととも に, 被覆する捨石の均し, 被覆石の設置, 均しに多 数の潜水士を要するなど工期が長くなる問題があっ た. 被要石の設置に時間がかかれば護岸が波により 被災する可能性も高くなる. また，被覆石の供給面 についても, 原石山の減少により大型の石材は供給 不足が予想され, コストの上昇が懸念される.

そこで，被覆石工法に代わる新しい施工法として, フィルターユニット（袋詰め砕石 : 写真-1）を用い た被覆工法を考案し, 実用化のための機能検証実験 を行った. 本工法を用いれば，工期の大幅な短縮だ けでなくコストダウンにつながる可能性がある. ま た，形状の小さな砕石が有効に利用できるため，材 料不足の心配が解消される.

本報は, フィルターユニットの特徵および施工法 について説明するとともに, 被覆石代替法としての 実用化を目的として行った水理実験の結果について 述べるものである.

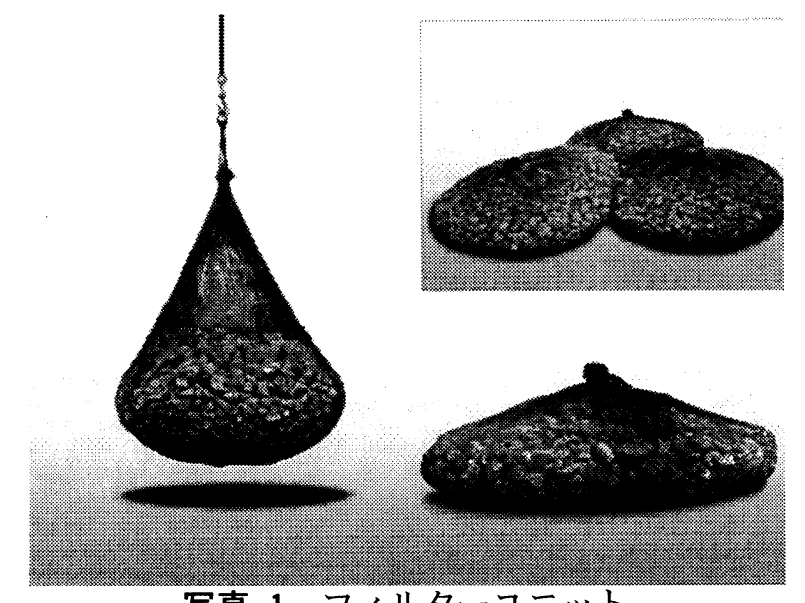

写真-1 フィルターユニット

\section{2. フィルターユニット工法}

\section{(1) フィルターユニットエ法の特徵}

フィルターユニット（通称F U）とは, 合成繊維 を使用した網袋に中詰め石を充填した材料であり,

これまで河川・海岸等の根固め, 洗掘防止, 護岸の 
間詰め等に使用されてきた. 写真-2 は, 明石海峡 大橋 $2 \mathrm{P}$ 主塔基礎の洗掘防止工に使用した F Uの施 工状況である. その大きな特徴としては,

(1)柔軟な構造体であるため, 設置面との馴染みが よく安定性に優れている.

(2)製作工・設置工ともに容易であるため，熟練工 を必要としない.

(3)網地のラッセル網は，無結節網に比べて破断し た箇所が広がりにくい構造である.

等が挙げられる。

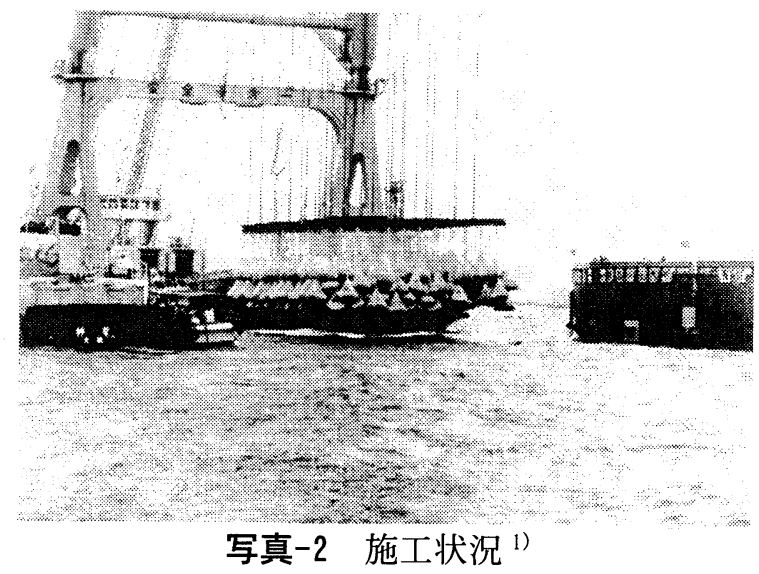

（2）施エフロー

図-1 にF U施工フローを示す。各作業項目とも に熟練工を要さず，工期短縮が可能な工法である.

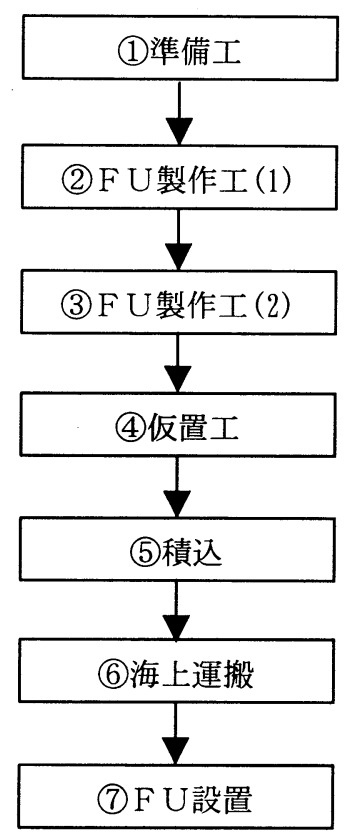

図-1＼cjkstart施工フロー

施工フローのうち，F U 製作工を図-2に示す，F Uの製作方法は，まず型枠にセットした網袋にバッ クホーで中詰石を投入する（製作工 (1)）。続いて， 吊環を取付けた F Uを仮吊し，口を縛り製作枠に玉 掛を行った後, トッラッククレーンにて引抜く（製 作工 (2)).
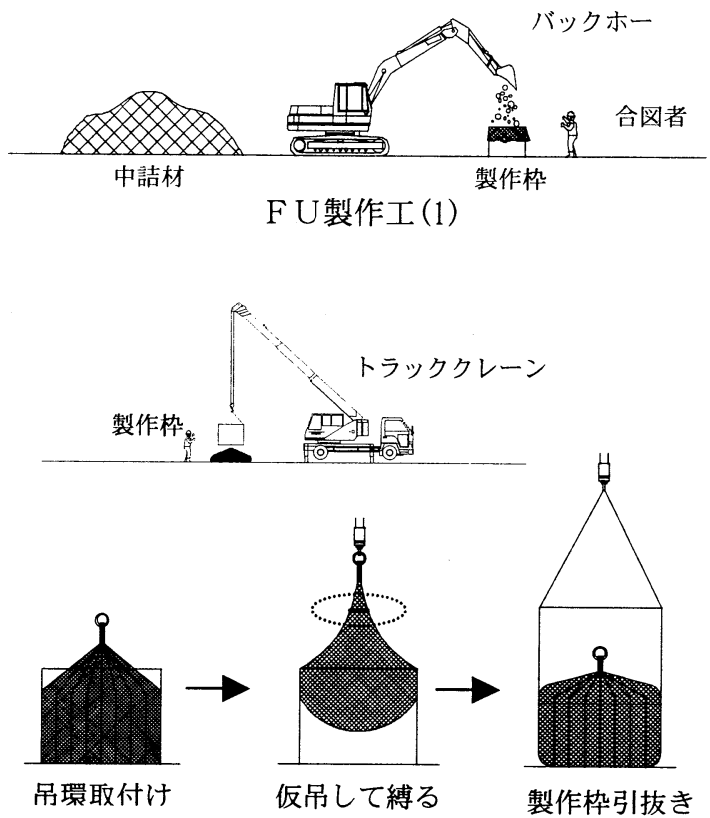

F U製作工 (2)

図-2 F U製作工

\section{(3) 検討断面}

図-3にFUの設置概念図を示す。今回の実験では, 一様水深部を持ち，比較的勾配の緩やかな捨石 (1) 上面には標準型（写真-1参照 : 丸型）を, 静水面付 近の比較的勾配の急な捨石 (2) 法面には直方体形状 をした角型をそれぞれ設置する案について検討した.

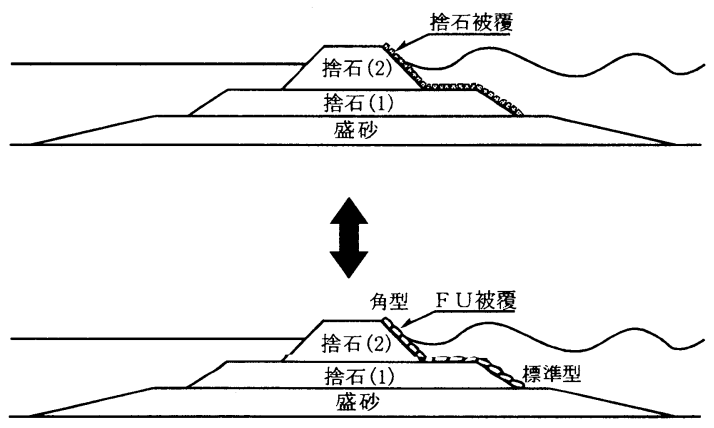

図-3ＦU設置概念図

\section{3. 耐波安定性確認実験}

\section{(1) 実験目的}

F Uは，これまで波力が作用する海岸護岸の永久 構造物として用いられた事例は少なく，波に対する 安定性の評価設計手法も確立されていない。また, F Uの中詰石の粒径が，背面に設置する捨石に比べ て小さく, 透水係数も低下するため, 局所的に大き な揚圧力が作用する可能性がある.

そこで，FU自身の耐波安定性とともに，上面に 設置する消波ブロックの安定性について検証を行つ た.さらに，FUの素材が合成繊維であることから， 長期使用に対する安定性についても検証を行った. 
（2）実験検討項目

今回の実験で検討した項目は以下の通りである.

（図-4 参照）

(1)施工時安定性確認実験

捨石 (1) 上面および捨石 (2) 法面に設置するF L し の 耐波安定性を検証し，捨石で被覆した場合の安定 性との比較を行う.

(2)完成時安定性確認実験

捨石 (2) の F U上面に設置する消波ブロックの耐 波安定性を検証するとともに, 捨石を設置した場 合の安定性との比較を行う.

(3)長期安定性確認実験

捨石 (2) 法面に設置した F Uが破れた場合の消波 ブロックの安定性を検証する.

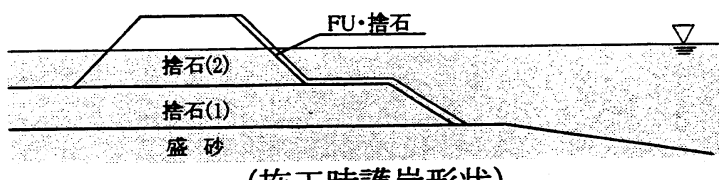

（施工時護岸形状）

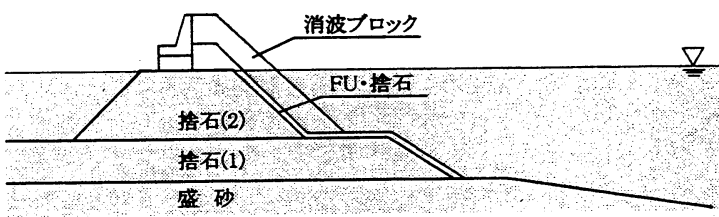

（完成時護岸形状）

図-4 実験概念図

実験では, 各護岸形状について作用する波高, 流 速および造波前後の断面変化, 消波ブロックの移動 状況について計測した.

\section{（3）実験方法}

\section{a) 実験模型}

これまで，F Uに関する水理模型実験はほとんど 行われていない。 そこで, 実験に先立ちF Uのモデ ル化について検討した. 今回の実験では, F U全体 の幾何形状, 質量だけでなく, 中詰石の粒径, 網材 の張力もできるだけ実物に近づけることを試みた.

写真-3 にF U模型を, 図-5 に実物との比較のた めに塞施した計測項目を示す．表-1 に実物と模型 の比較結果を示す.

今回使用した模型は，実物に比べ中詰石の粒径が

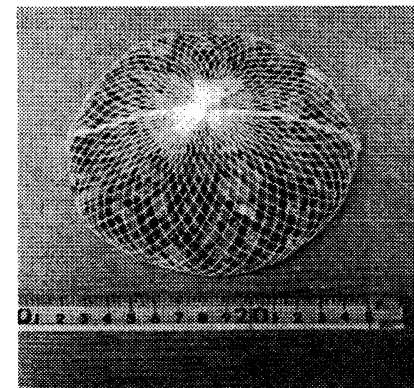

（標準型）

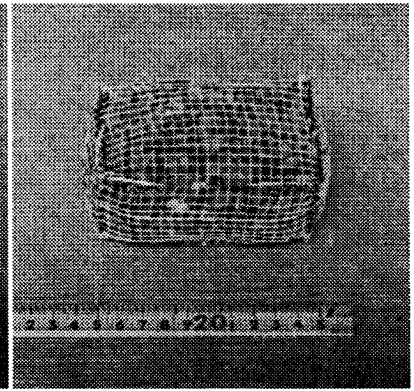

（角型）

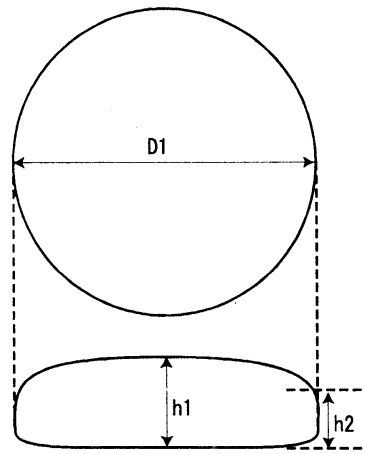

設置状態

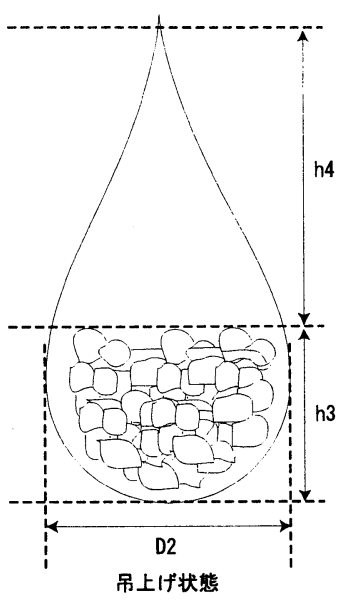

図-5 F U形状の計測項目
大きく, さらに網地の直径が太かった. そのため, 標準型は実物に比べ伸びが小さい硬めの模型となり, 馴染みが若干弱かった。設置状態において実物では, F U上面においても網袋には張力が作用しており, 隙間無く中詰石を拘束している．模型は，網材がや や硬めであるため若干隙間が存在したが，設置状態 の全体形として，ほぼ実物を再現することが出来た. 一方, 角型は形が安定しやすいため, ほぼ所定の 形状を満足する模型を製作することが出来た.

表-1～F U形状計測結果（標準型）

\begin{tabular}{|c|c|c|c|c|c|c|c|c|}
\hline \multirow{3}{*}{ FU } & \multicolumn{3}{|c|}{$\begin{array}{c}\text { 設置状態 } \\
\text { (m) }\end{array}$} & \multicolumn{3}{|c|}{$\begin{array}{c}\text { 吊り下げ状態 } \\
(\mathrm{m})\end{array}$} & $\begin{array}{c}\text { 使用網 } \\
(\mathrm{mm})\end{array}$ & $\begin{array}{c}\text { 使用石 } \\
(\mathrm{mm})\end{array}$ \\
\hline & \multirow{2}{*}{ D1 } & \multirow{2}{*}{ h1 } & \multirow{2}{*}{ h2 } & \multirow{2}{*}{ D2 } & \multirow{2}{*}{ h3 } & \multirow{2}{*}{ h4 } & D & \multirow{2}{*}{$d$} \\
\hline & & & & & & & L & \\
\hline \multirow{2}{*}{ 実物 } & \multirow{2}{*}{2.93} & \multirow{2}{*}{0.65} & \multirow{2}{*}{0.32} & \multirow{2}{*}{2.45} & \multirow{2}{*}{0.92} & \multirow{2}{*}{1.65} & 2.5 & \multirow{2}{*}{$50 \sim 150$} \\
\hline & & & & & & & 50 & \\
\hline \multirow{2}{*}{ 模型 } & \multirow{2}{*}{2.49} & \multirow{2}{*}{0.78} & \multirow{2}{*}{0.41} & \multirow{2}{*}{2.26} & \multirow{2}{*}{0.93} & \multirow{2}{*}{0.89} & 7.14 & \multirow{2}{*}{$100 \sim 200$} \\
\hline & & & & & & & 188.56 & \\
\hline
\end{tabular}

$D ：$ 網地直径

L : 目合い

\section{b) 実験条件}

実験は, 長さ $60.0 \mathrm{~m}$, 幅 $2.0 \mathrm{~m}$, 高さ $2.0 \mathrm{~m}$ の 2 次 元造波水路を用いて行った. 今回対象とした波浪条 件を表-2 に示す．ただし，作用する波は水深によ って変化するが, 検証する捨石 (1) 上面, 捨石 (2) 上 面の水深も異なるため, 同じ波浪条件に対し水深を 2 通りに変化させて実験を行った.

表-2 波浪条件

\begin{tabular}{|c|c|c|c|}
\hline $\begin{array}{l}\text { 有義波高 } \\
\text { 有義周期 }\end{array}$ & $1.7 \mathrm{sec}$ & $2.0 \mathrm{sec}$ & $2.2 \mathrm{sec}$ \\
\hline $18.1 \mathrm{~cm}$ & Case 1 & $\cdots$ & -- \\
\hline $24.4 \mathrm{~cm}$ & -- & Case2 & --- \\
\hline $31.1 \mathrm{~cm}$ & --- & -- & Case3 \\
\hline
\end{tabular}

写真-3 F U 模型 


\section{c)模型セットアップ}

図-6 に標準型と角型の F Uの設置概念図をそれ ぞれ示す．標準型は前後左右を重ねながら六角形状 に, 角型は 1 個 1 個を密着させながら，ともに一列 ずつ千鳥状に設置した。

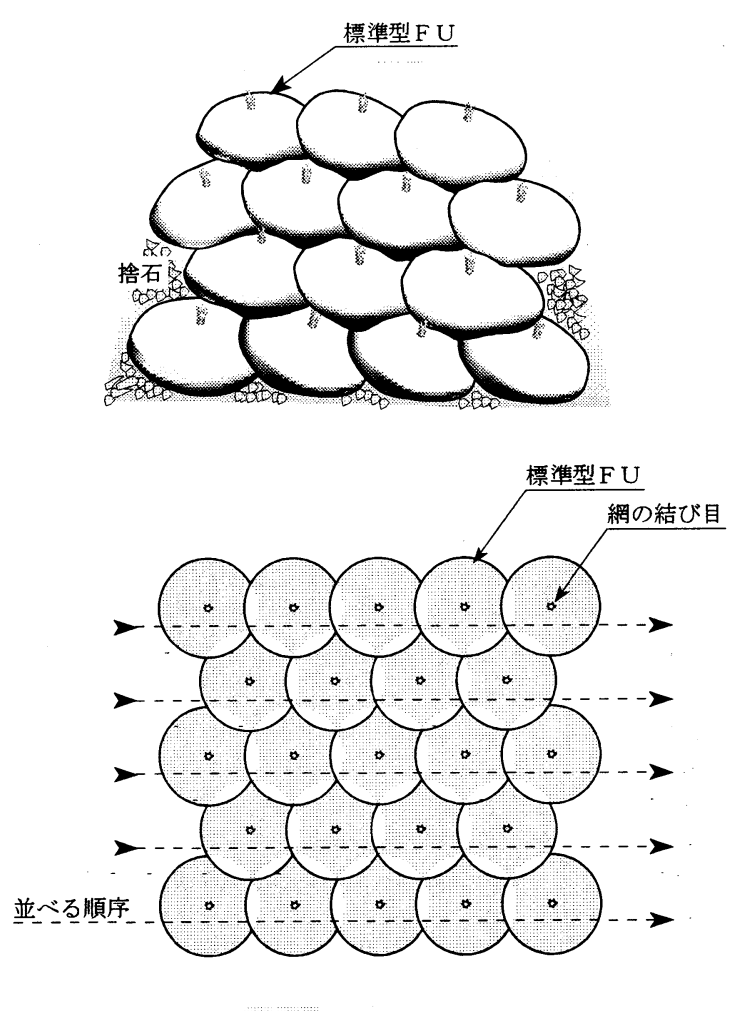

（標準型） d) 計測方法と比較断面

図-7 に施工時の計測地点を示す. 護岸模型は水 路の中央付近に設置し, 比較のために模型の半分は, F Uの厚みと被覆厚さが同程度となる捨石（重量は FUの 1／4）により被覆した。作用波高・流速は 縦断方向 3 地点で, 断面変化は横断方向 4 測線でそ れぞれ計測した。
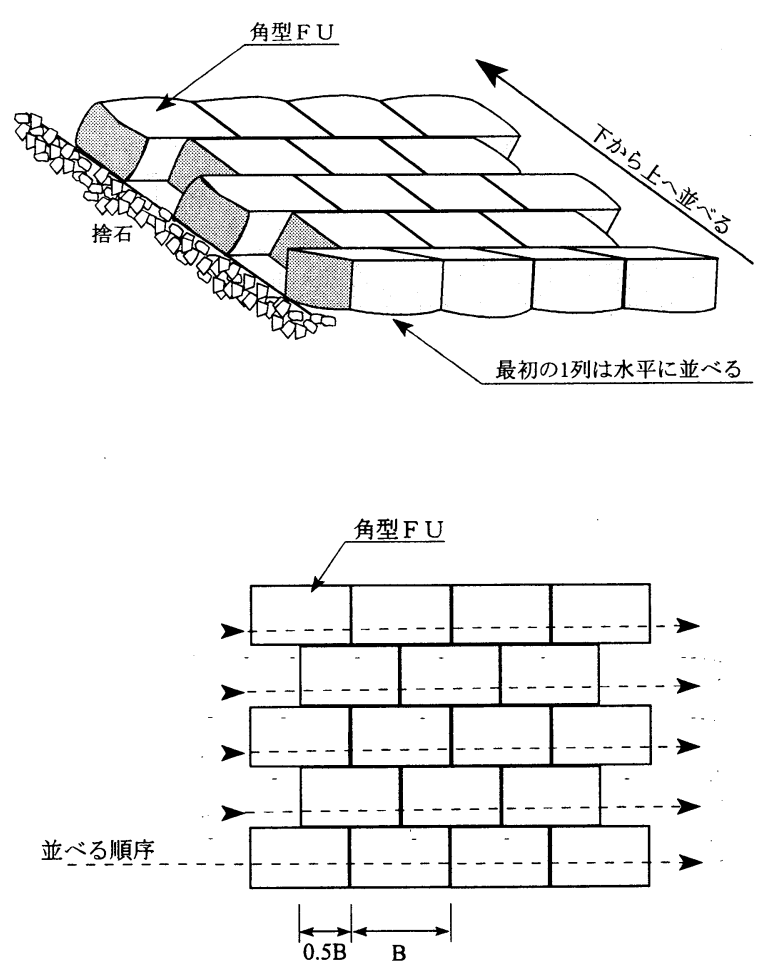

（角型）

図-6Ｆ U設置方法

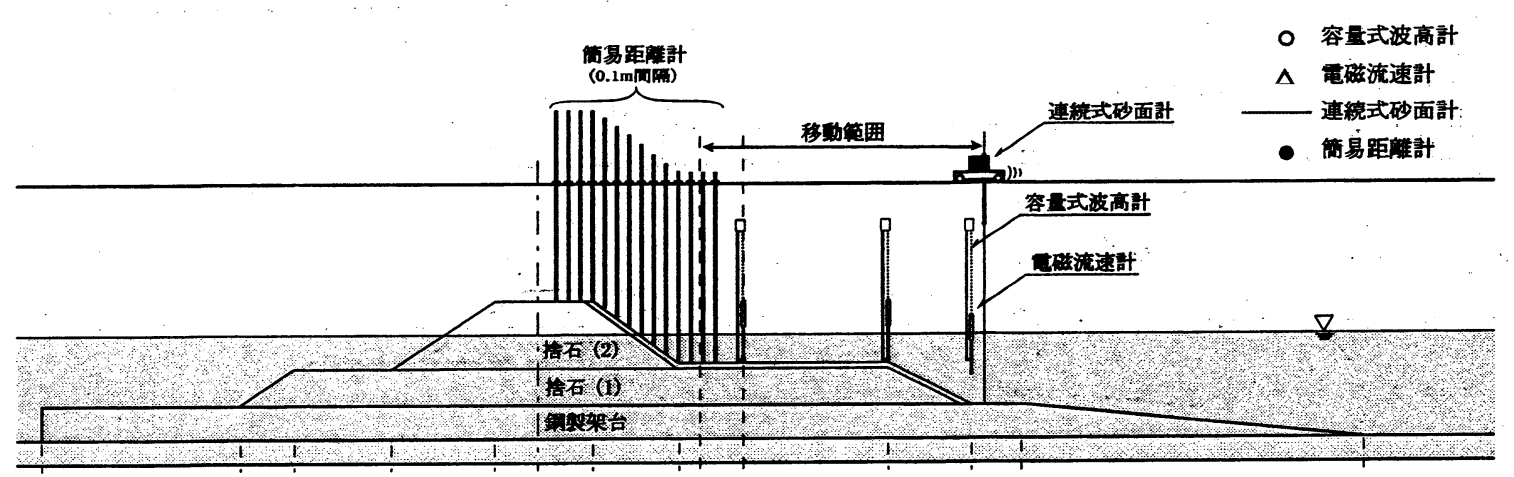

断面図

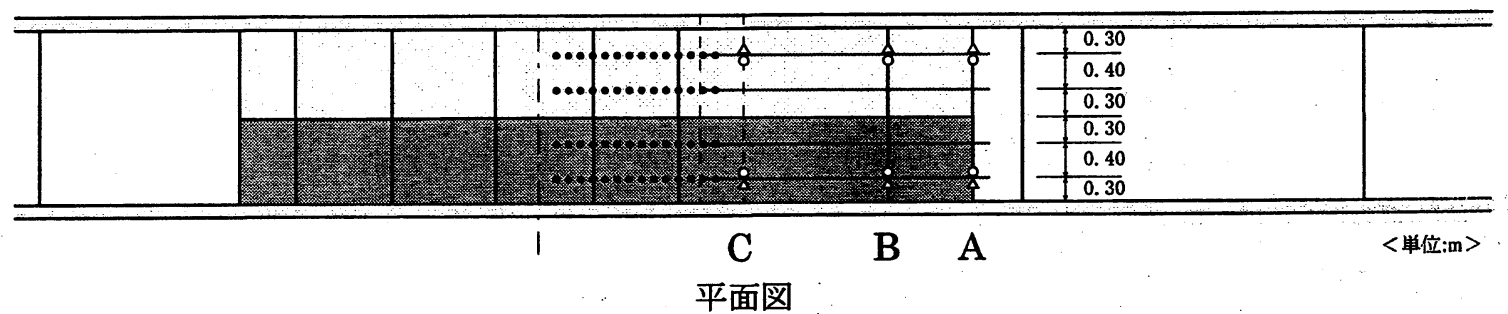

図-7 計測地点 


\section{（4）実験結果}

a) 施工時安定性確認実験

写真-4に施工時の護岸模型を，写真-5に実験状況 をそれぞれ示す。

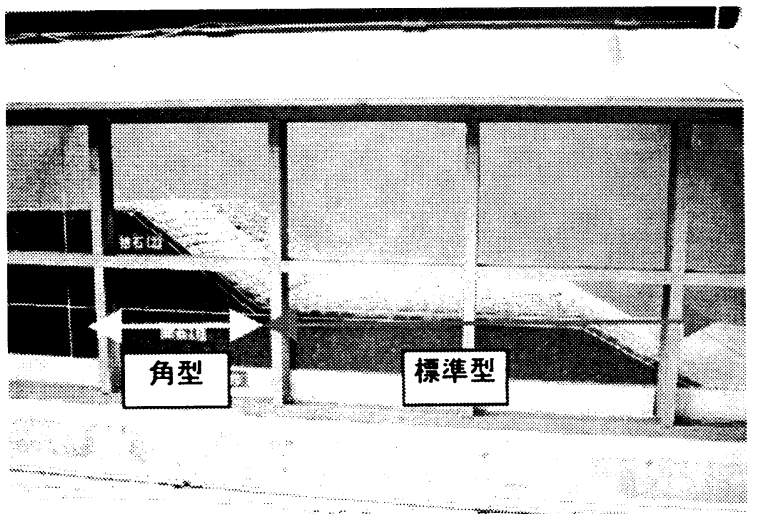

写真-4 施工時護岸模型

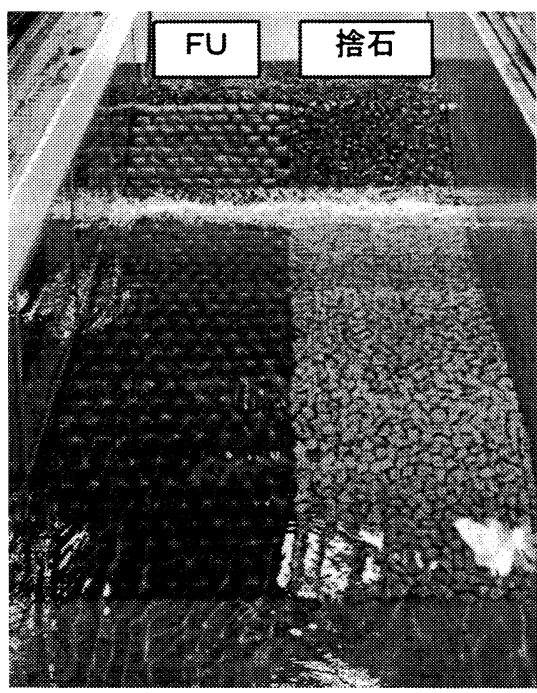

写真-5 施工時実験状況

写真-6 は，施工時の波浪条件（Case1 : 有義波高 $18.1 \mathrm{~cm}$, 有義周期 $1.7 \mathrm{sec）}$ に対する捨石 (2) 法面の 変化の様子を, 初期状態と 1000 波作用後について 示したものである。.また図-8 は，初期形状，1000 波作用後, 3000 波作用後の断面形状を示したもの である。

これらの結果を見ると，捨石で被覆したでは捨石 (1) の法肩付近の石が崩れるとともに, 捨石 (2) 法面 が S 字型に変形していることがわかる. 特に, 波が 直接作用する捨石 (2)法面については，表面の捨石 が剥がされた箇所から背後の石が徐々に吸い出され, 500 波作用後には断面は大きく崩れていた.

一方，F Uで被覆した箇所はほとんど断面変化は 見られず，捨石 (2) 法面についても非常に安定して いる.

なお，捨石が崩れる傾向は，水深が小さい場合に 顕著となり, Case1 より条件が厳しい Case2 の場合 はその範囲がかなり拡大したが，F U設置箇所につ いてはその場合でも大きな変化は見られず，非常に 安定性に優れていた.

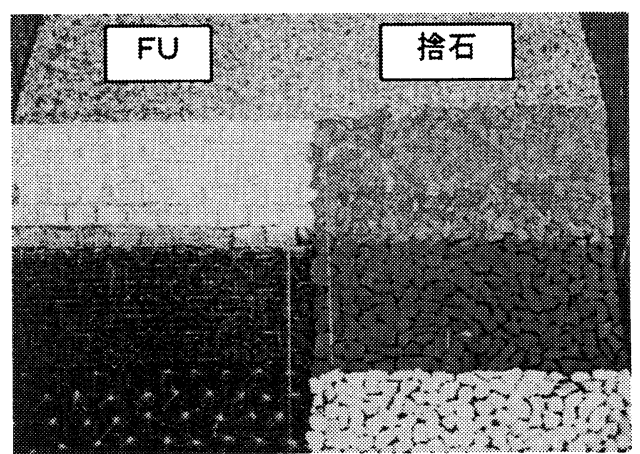

（初期状態）

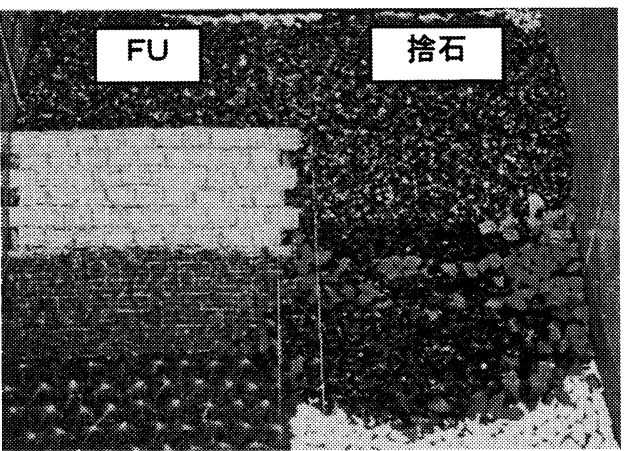

(1000 波作用後)

写真-6 断面変化状況
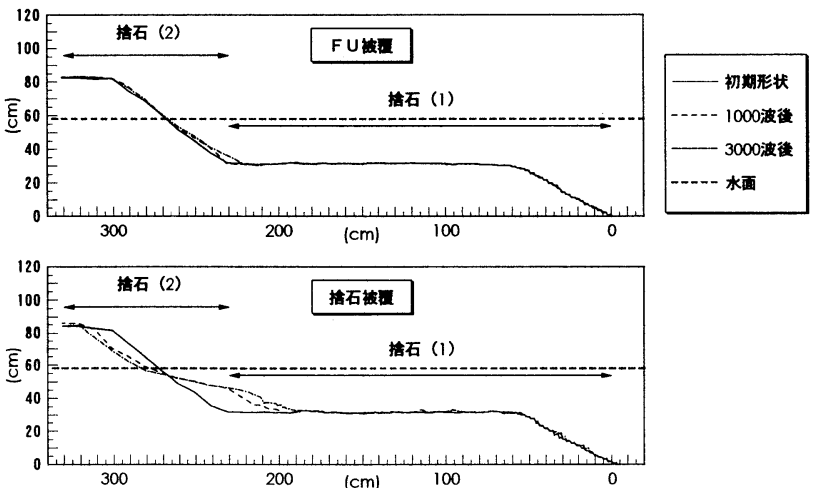

図-8 断面変化計測結果

b) 完成時安定性確認実験

写真-7に完成時の護岸模型を, 写真-8に実験状況 をそれぞれ示す。

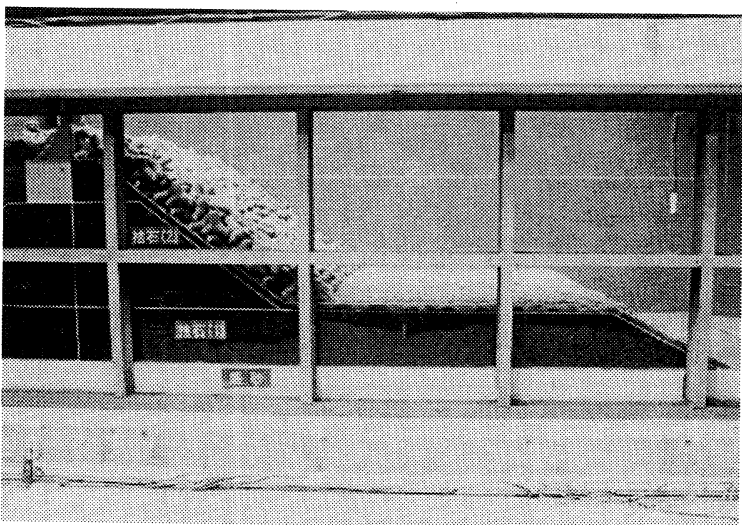

写真-7 完成時護岸模型 


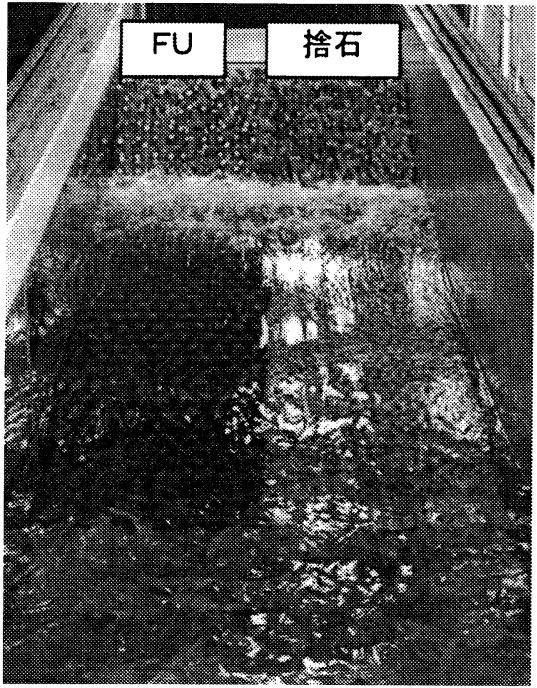

写真-8 完成時実験状況

F Uに用いる中詰石の粒径は背後の捨石 (2) に比 べて小さく，設置面で透水係数が低下する．そのた め, 局所的に大きな揚圧力が作用し, 消波ブロック の安定性に影響を及ぼすことが心配された.

しかし，捨石の領域と同様に，F Uを設置した領 域についても消波ブロックの移動はほとんど見られ ず，透水係数の変化はブロックの安定性に大きな影 響を与えないことがわかった（写真-9参照）.

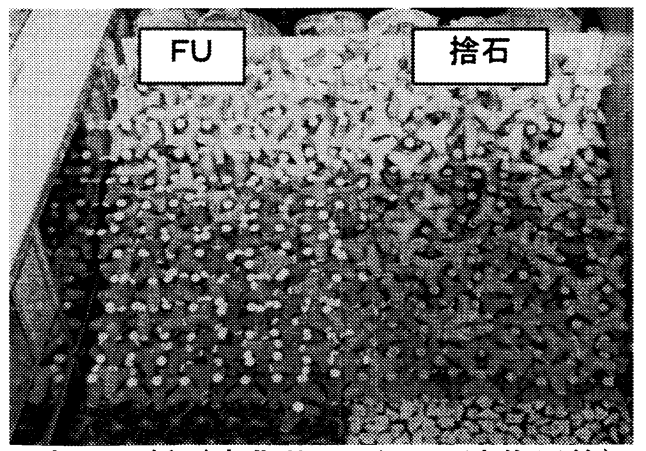

写真-9 断面変化状況（1000 波作用後）

\section{c）長期安定性確認実験}

F Uが破れた状況として，FUに代わり中詰石を 設置した状態で波を作用させても，消波ブロックの 隙間から短期間に石が吸出されることはなく，また 消波ブロックの安定性にも問題はなかった.

\section{4. 結論および今後の課題}

実験で得られた結論および今後の課題は以下の通 りである.

\section{(1)結論}

\section{a) モデル化}

- 全体の幾何形状, 質量だけでなく, 中詰石の粒径, 網材の復元力の相似を保つよう努めることにより, ほぼ実物に近い模型を再現することができた。

\section{b) 実験結果}

・F Uは捨石による被覆に比べて耐波安定性が優れ ており, 従来工法と同等以上の機能が期待できる.
・F U上面に設置した消波ブロックに局所的な揚圧 力は作用せず，十分安定性が確保されている.

・F Uが破れた場合でも, 内部の捨石が急激に吸出 されたり消波ブロックが崩れることは無い.

c)耐波安定性の向上の要因

- F Uは, その柔軟な構造により設置面やF U同士 の馿染みがよく, マットの様に一体となって機能 する.

・その一方で, 個々のF Uは小さな石により構成さ れ, 高い透水性を持つため, 同じ体積の捨石に比 ベ, F Uは全体として受ける力が小さい.

\section{(2) 今後の課題}

\section{a) 耐磨耗特性の評価}

F Uはその素材が合成繊維（ナイロン）であるた め, 海岸護岸に用いるには磨耗に対して網の耐久性 を確保することが重要な課題であり, 耐磨耗特性の 試験方法, 評価手法を確立し, 長期間の使用に対し て網の耐久性を予測する必要がある．そのための手 法としては,

・磨耗試験装置による実物の要素試験

・実物大の大型造波装置を用いた耐久試験

・実海域における而久性試験 が考えられる.

\section{b) 耐波設計法の確立}

今回の実験では，ひとつの断面形状に対して，F Uの安定性を水理模型実験により検討した. 今後, コストダウンを含めた詳細な検討を行うためには, F Uの耐波設計法を確立し，任意の波浪条件，断面 形状に対してF Uの安定重量, 形状を求めることが 重要である.

\section{5. おわりに}

実験の結果, フィルターユニット工法は従来の被 覆石工法と同等以上の耐波安定機能を有することが わかった。 また，本工法は工期短縮とコストダウン が期待できる工法であり, 将来的には建設廃材の有 効利用に繋がる可能性もある.

本工法を実用化していくためには，上記の課題の 検討を行うとともに, 実海域での試験施工を通じて 機能・効果の確認・実証を行うことが重要であると 考えられる.

謝辞 : 本研究の遂行にあたり, 大阪大学大学院出口 教授よりご指導を得た。ここに記して謝意を表する 次第である.

\section{参考文献}

1）本州四国連絡橋公団, 明石海峡大橋 $2 \mathrm{P}$ 下部 工 J V : 明石海峡大橋 $2 \mathrm{P}$ 下部工工事写真集, p. 49, 1992. 